\title{
COMPUTER ANALYSIS OF' ANTHROPOMETRIC MEASUREMENTS ON PHOTOGRAPHS FOR FACIAL IDENTIFICATION OF ADULT EGYPTIAN MALES
}

\author{
BY
}

Eman M. Soliman and Mona M. Zoair*

Departments of torensic Medicine \& Clinical Toxicology and Anatomy \& Ehbryology*. Faculy of Medicine, Tania University. Esyp

\begin{abstract}
Today, thronghom the world. photographs are still used as a method of identificution. Attempis to recognise the Egypticm photographs by computer programs are less frequent than those of the recognition of some oiher phenomena in everyday life. The purpose of the present surly svas to identify the aduh Esyprian face by tracing facial features and computer analysis of anthropometric measurements from the photogmphs. Two handred sets of photogriphs (n'o phorographs for cach individual, the duration beween the first and second photograph tanged from 3.5 years) showing facial features of Egyptian male rolumeers aged fiom 28 to 62 years were obtained by standard photographic technigue and scanned onto computer diskelle. Fiffeen differen facial features weic exumined. Also, fourteen anthropometric measurements assessing the facial dimensions vere measured by CorelDraw progran (version 6) and compared between the two photographs of cach individual. The morphological results showed that the fair huir and asymmetrical external eycbrow ends were the poverfut discriminators between two photostruphs. Computer analysis of the objecrive dnta revealed no significant differences betwecn the two phosographs in all anthropomenic measurements. No differences were observed between the two photographs in both interpupillary distance and widh of one cyc. While, the highest differences between two phongraphs were obvious in the mouth widh on oral fissure line, followed by tength of forehead but stilt . insignificant. The present study demonsmated the benefit of computer programs to forensic field. At the sume time, it illusfrated that anhropometric measurements were the most accurate method of compatison between two photographs of the sume person. Finally, this study suggests that photographs may be, used as physical evidence when compared wilh known photographs of a suspect as they form somewhat of a signume of the suspeat that is left behind on the evidence.
\end{abstract}

\section{INTRODUCTION}

The human face is a characteristic pattern most familiar to us when distin - guishing people. Although recognizing human faces is one of our everyday activities, we are mostly not aware how the recognition actually works (Vezjak 
and Stephancic; 1994).

The use of photographs to determine people 's identity has been used by authorities since the middle of the nineteenthcentury. The increase in the use of photographs on individual identification credentials such as driving licenses, credit cords, security passes and passports has led, for the purpose of criminal activities, to facilitate identification of crime suspects by image comparison (Vanezis et al., 1996; Porter and Doran, 2000).

There have been numbei of studies carried out to assess facial leatures to improve the reliability of identilication based (n) intage comparison. These have been based on a consideration of anthropometric and morphometric parameter assessment or combination of both (Catterick, 1992).

Today, with the development and establishment of fingerprint technology, fingerprints becaime more widely used than the carly photographs and proved to be a more reliable method of identification. On the other hand, fingerprint identification requires trained and qualified eyes and a fingerprint expert. Also, photographs are used so that a lay person, including customs officials, can make cursory identification by comparing the suspect in question with his/ her photograph (Knight, 1996; Porter and Doran, 2000).
The doctor should never risk an opinion on examining photographs, as he should remember that he is not an expert in photography whereas a photographer or an artist is better qualified to give an opinion on such a point (Fraklin, 1988). Measurements of the human face as a part of modern anthropometry mainly serve forensic and medical purposes. For reconstructive and cosmetic surgery, realistic sizes and proportion are assessed using anthropometric techniques and used as guidelines to correct deformities or disproportions (Vegter and Hage, 2000). Also in photo-superimposition, photographs of the skull are taken in exaclly the same orientation in three planes as the available photograph (Miyasaka et al., 1995; Aulsebrook et al., 1996).

The identification method for facial comparison has four separate components (Porler and Doran, 2000):

1-Individual facial characteristics (scars, moles, dimples).

2-Facial symmetry.

3-Form, size and shape of facial features (nose, eyebrows, mouth, ears, forehead creases).

4-Anthropometric measurements.

The forensic anatomist must possess a sophisticated knowledge and practical skill in craniofacial anatomy. Because experienced anatomist, are not always available for this type of examination. Also, 
cosmetic changes may affect the first three methods of facial comparison. So, anthropometric measurements are the most accurate method of identification (Loh and Chao, 1989).

Direct examination of original document photographs is often difficult due to the small size of the images, which are of ten different magnifications. The first stage of the present study was to reproduce the original photographs as larger sized prints and at the same magnification. The equivalent image was critical to the validity of the anatomical comparison to be made. Then, the second stage described, automalic technique, enabling accurate anthropometric measurements and tracing of facial features, which allowed direct physical comparison of document images for easy identification of the Egyptian face.

\section{MATERIAL AND METHODS}

An anthropometric study was devised to examine the facial proportions of the Egyptian face. One hundred Egyptian male; wolunteers between the ages of 28 and 62 years were photographer (frontal view) by standard photographic technique. Another frontal view photograph from each individual was taken after 3-5 years from the first one. Two photographs of each individual were ransmitted onto computer diskette by sanner. The two photographs were inagnified into the same magnifications by the computer, and then fifteen different types of facial feature categories were examined and the appropriate feature from the subset was selected. Also, fourteen anthropometric measurements of each photograph were taken for comparison between two photographs of each individual (Salmons, 1995). All measurements were made using CorelDraw program version 6 (to the nearest $0.05 \mathrm{~mm}$.).

\section{Statistical Analysis:}

The data of facial features was presented as number and percent distribution. The lest of significance $(\mathrm{Z})$ was calculated to compare the difference between observed proportions among the Egyptians and the Caucasians. Statistical comparisons were done between the two photographs of each Egyptian individual in all anthropometric measurements using the mean, standard deviation and paired " $\mathrm{t}$ " test. Significance was adopted at $P<0.05$. All statistical analyses were performed by using the SPSS software statistical computer package version 12 (Dawson- Saunders and Trapp, 1994).

Anthropometric measurements (as shown in Fig. 1) were taken according to Salmons, (1995); Bush and Antonyshyn, (1996) and Porter and Doran, (2000) as the following:

1- Interpupillary distance: the horizon- 
tal distance between the centers of both pupils.

2-Horizontal face width between the two ear roots: the distance between two ear roots parallel to interpupillary line and crossing the midline.

3- Mouth width on the oral fissure line: the distance between the widest points of the red-lip margins.

4-Nose width at the widest points of the alae (wings of the nostrils).

5-Length of the forehead: the distance from the hair line to the root of nose.

6-Length of the nose: the distance from its root to its tip.

7-Length of the mouth and chin: the distance from the tip of nose to the edge of chin.

8-Distance between the eyes: area be.. tween the two inner canthi.

9-Width of one eye(the left eye): the distance between inner canthus and outer canthus.

10- Distance between the nostril and the oral parting: the distance from the tip of nose to the horizontal line between both l:ps.
11- Distance between the oral parting and the mental sulcus.

12- Distance between the mental sulcus and the edge of the chin.

13- Length of one ear (the left ear): the distance from the highest point of the helix to the lowest point of the lob ule.

14- Length of one eyebrow (the left eyebrow): the distance from medial to lateral ends of the arched hairy eminence surrounding the orbit.

\section{RESULTS}

The morphological results of facial features showed that number of features were of little value as discriminators. Table (1) revealed that the most unreliable and unpredictable feature subsets in the Egyptians were: the dark hair $(70 \%)$, oval eye $(63 \%)$ and curved eyebrow $(57 \%)$. Furthermore, the best discriminators were those features in which agreement was high and feature occurrences in the photographs were relatively low. It was relatively easy to agree on what a dark hair was, with frequency in the population of about $70 \%$. On the other hand, the fair hair and asymmetrical external eyebrow ends had a frequency of $3 \%$ and $5 \%$ respectively, thus making these features powerful discriminators. 
The best discriminalors in Caucasians were asymmetrical face, frizzy hair and asymmetrical external eyebrow ends $(0.6$ $\%$. Whereas, the unreliable and unpredictable feature subsets were the down exlernal eyebrow ends ( $85.2 \%)$, oval eye $(79.8 \%)$, slight nostril visibility (74.8\%) and both dark hair and rounded nose tip $(66 \%$ \% $)$ (Z) test illustrated the differences in percentage between Egyptian and Caucasian facial features (Table 1).

Table (2) demonstrated a comparison between the two photographs as regards the anthiopometric measurements. There were no significant "differences between the two photographs in all anthropometric measurements.

The highest mean differences with highest percentage change between two photographs were obvious in the mouth width on oral fissure line $(0.010 \pm 0.346$ with percentage change 0.81 ), followed by length of forehead $(0.008 \pm 0.099$ with percentage change 0.54): While the lowest mean differences with lowest percentage change between the two photographs were observed in length of ear "left ear" $(0.0002 \pm 0.006$ with percentage change 0.02 ) and length of eyebrow "left eyebrow" $(0.0005 \pm 0.014$ with percentage change $0.02)$.

Moreover, a gradual increase in the differences between two photographs was obscrvedin. length of mouth and chin $(0.001 \pm 0.032$ with percentage change $0.02)$, the horizontal face width between two ear roots $(0.002- \pm 0.017$ with percentage change 0.05$)$, distance between nostril and oral parting $(0.002 \pm 0.012$ with percentage change 0.13 ), distance between two inner canthi $(0.002 \pm 0.087$ with percentage change 0.13), distance between oral parting and mental sulcus $(0.002 \pm$ 0.011 with percentage change 0.25 ), nose width at the widest points of alae $(0.004 \pm$ 0.109 with percentage change 0.21 ) and length of the nose $(0.005 \pm 0.039$ with percentage change 0.33 ).

The present study revealed no differences between two photographs in both interpupillary distance and width of one eye "left one".

\section{DISCUSSION}

Forensic photography, although similar to medical pholography, has differenl aims, and different objectives. The main consideration is that the images are taken primarily for legal reasons, therefore the results must be accurate, detailed and of use in court. The photographer must have an understanding of the technical requirements as well as the related medical and legal requirements (Henham and Lee, 1994).

Anthropometry currently provided the 
most widely accepted and clinically useful method for quantitative assessment of facial anatomy (Bush and Antonyshyn, 1996). According to this techrique, the present study proved that by using $14 \mathrm{fa}$ cial measurements in norma frontalis, it was possible to analyze, recognize and identify the adult Egyptian face.

As long ago as 1878 , attempts had been made to define photographically the typical facial characteristics of persons exhibiting particular appearances or afflictions. State of the art numerical computing techniques facilitate definition of highly accurate facial composites (Benson, 1994).

Techniques that depend on measurements rather than strictly morphological parameters needed to be based on standardized photographs for assessment. So, the present study used CorelDraw program (version 6) to measure the facial dimensions from Egyptian photographs and compare between two photographs of each individual. This technique served as the current standard of quantitative facial assessment and has been used in the description of normal facial proportions (Farkas et al., 1985; Farkas and Kolar, 1987), in the determination of characteristic features in various craniofacial malformations and even to provide a normative database (Farkas et al., 1977 \& 1989).

Referencewise, photographs of the front and profile views of the face may serve as a means of identification. The details of the features as regards the eyes, nose, ears, lips, chin and teeth should be carefully noted. The bridge of the nose may be narrow, flat or broad, and the nostrils may be distended or the reverse. The ears may be small or large in size. The lips may be thin or thick and the upper lip may hang over the lower lip, or may look shorter owing to the upper incisor teeth projecting outwards. The chin may be rounded, square or protruding (Knight, 1996).

The present study revealed that fair hair, asymmetrical external eyebrow ends, asymmetrical face, white and bald hair, were the best discriminaiors an facia: $f_{\text {sii }}$. fures. Ori the other hand, tark hair, orat eye and curved eyebrow were the most unreliable features.

Vanezis et al., (1996) reported that the best discriminators in Caucasians were asymmetrical face, frizzy hair and asymmetrical external eyebrow ends. They also illustrated that the unreliable and unpredictable feature subsets were the down external eyebrow ends, oval eye, slight rostril visibility, dark hair and rounded nose tip.

In the present study, the mouth width on oral fissure line and the length of forehead showed the highest differences between two photographs. The highest dif- 
ferences in the mouth width on oral fissure line might depend on the degree of smiling, while the length of forehead might be due to alopecia, which occurs in maie especially in old age.

In this study, the lowest differences between two photographs were observed in length of one ear, and length of one eyebrow. These differences may be attributed into error in determining the accurate site, which must be measured by CorelDraw program in both photographs. These findings were coincided with Bush and Antonyshyn, (1996) who reported that the errors in localization of anatomical landmarks by computer program were minimal. This reflected the ability of the user to visualize anatomical landmarks adequately on the computer image and localize them without direct palpation of the surface.

CorelDraw program in this study demonstrated no differences between two photographs in both interpupillary distance and width of one eye. These findings were partially in agreement with Porter and Doran, (2000) who mentioned that interpupillary distances $(44 \mathrm{~mm}$ ) and horizontal face width between ear roots $(99 \mathrm{~mm})$ were equal in both photographs, while mouth width on oral fissure line decreased 1.5 $\mathrm{mm}$ and the nose width on septal /lip line decreased $0.5 \mathrm{~mm}$ between first and second photographs when the same magnification was done for the two photographs.

The present study concluded that, computer programs were very useful to forensic field and revealed that anthropometric measurements were the most accurate method of comparison between two photographs of the same person.

\section{RECOMMENDATIONS}

This study suggests that the use of identification photographs from falsified credentials may be considered useful as an investigative tool to obtain physical evidence. At the same time, the technique described in this paper is one, which produces physical evidence with which it is difficult to tamper, and in the current legal climate is more acceptable.

\section{Acknowledgment:}

The authors would like to thank Prof. Dr. Ebrahim Kabbash, Professor of Public Health, Faculty of Medicine, Tanta University for his great help and cooperation to do the statistical analysis in this work. 
Table (1): Proposed facial morphological classification in Egyptian males versus Caucasian males.

\begin{tabular}{|c|c|c|c|c|c|}
\hline $\begin{array}{l}\text { Features } \\
\text { Category }\end{array}$ & Subset & $\begin{array}{l}\text { Percentage \% } \\
\text { in Egyptian } \\
\text { males }\end{array}$ & $\begin{array}{l}\text { Percentage \% } \\
\text { in Caucasian } \\
\text { males }\end{array}$ & $Z$ & $P$ \\
\hline I-Facinl form & $\begin{array}{l}\text { 1-Round } \\
\text { 2-Oval } \\
\text { 3-Square } \\
\text { 4-Angular down } \\
\text { 5-Asymmetrical } \\
\text { 6-Angular up }\end{array}$ & $\begin{array}{l}10 \% \\
28 \% \\
19 \% \\
36 \% \\
7 \% \\
-\end{array}$ & $\begin{array}{l}6.8 \% \\
39.4 \% \\
20 \% \\
26.8 \% \\
0.6 \% \\
2 \%\end{array}$ & $\begin{array}{l}0.561 \\
1.556 \\
0.00 \\
1.249 \\
0.00 \\
0.711\end{array}$ & $\begin{array}{l}0.575 \\
0.120 \\
1.000 \\
0.212 \\
1.000 \\
0.477\end{array}$ \\
\hline 2-Hair colour & $\begin{array}{l}\text { J-Dark } \\
\text { 2-Fair } \\
\text { 3-Grey } \\
\text { 4-White }\end{array}$ & $\begin{array}{l}70 \% \\
3 \% \\
20 \% \\
7 \%\end{array}$ & $\begin{array}{l}66 \% \\
23.4 \% \\
8.6 \% \\
1.8 \%\end{array}$ & $\begin{array}{l}0.455 \\
4.053 \\
2.101 \\
1.448\end{array}$ & $\begin{array}{l}0.649 \\
0.001^{*} \\
0.036^{*} \\
0.148\end{array}$ \\
\hline 3-Hair length & $\begin{array}{l}\text { I-Long } \\
\text { 2-Medium } \\
\text { 3-Short } \\
\text { 4-Partially bald } \\
\text { 5-Bald }\end{array}$ & $\begin{array}{l}10 \% \\
32 \% \\
38 \% \\
13 \% \\
7 \%\end{array}$ & $\begin{array}{l}7.4 \% \\
36.6 \% \\
50.8 \% \\
2.6 \% \\
1.8 \%\end{array}$ & $\begin{array}{l}0.401 \\
0.536 \\
1.679 \\
2.479 \\
1.448\end{array}$ & $\begin{array}{l}0.688 \\
0.592 \\
0.093 \\
0.013^{\star} \\
0.148\end{array}$ \\
\hline 4- Hair form & $\begin{array}{l}\text { 1-Straight } \\
\text { 2-Wavy } \\
\text { 3-Curly } \\
\text { 4-Frizzy }\end{array}$ & $\begin{array}{l}9 \% \\
30 \% \\
45 \% \\
16 \%\end{array}$ & $\begin{array}{l}65.2 \% \\
20 \% \\
14.2 \% \\
0.6 \%\end{array}$ & $\begin{array}{l}8.080 \\
1.470 \\
4.616 \\
2.034\end{array}$ & $\begin{array}{l}0.001^{*} \\
0.142 \\
0.001 \text { * } \\
0.042^{\star}\end{array}$ \\
\hline 5-Eyebrow shape & $\begin{array}{l}\text { 1-Straight } \\
\text { 2-Curved } \\
\text { 3-Arched }\end{array}$ & $\begin{array}{l}43 \% \\
57 \% \\
- \\
\end{array}$ & $\begin{array}{l}15.8 \% \\
62 \% \\
22.2 \%\end{array}$ & $\begin{array}{l}4.066 \\
0.576 \\
4.772\end{array}$ & $\begin{array}{l}0.001^{*} \\
0.564 \\
0.001^{*}\end{array}$ \\
\hline $\begin{array}{l}\text { 6- Elebrow } \\
\text { density }\end{array}$ & $\begin{array}{l}\text { 1-Sparse } \\
\text { 2-Thick } \\
\text { 3-Bushy }\end{array}$ & $\begin{array}{l}31 \% \\
54 \% \\
15 \%\end{array}$ & $\begin{array}{l}31.8 \% \\
49.2 \% \\
8.6 \%\end{array}$ & $\begin{array}{l}0.030 \\
0.538 \\
1.184\end{array}$ & $\begin{array}{l}0.978 \\
0.591 \\
0.237\end{array}$ \\
\hline $\begin{array}{l}\text { 7-External } \\
\text { ẹebrow ends }\end{array}$ & $\begin{array}{l}\text { I-Up } \\
\text { 2-Horizontal } \\
\text { 3-Down } \\
\text { 4-Asymmetrical }\end{array}$ & \begin{tabular}{|l|}
$8 \%$ \\
$31 \%$ \\
$56 \%$ \\
$5 \%$
\end{tabular} & $\begin{array}{l}1.4 \% \\
12.2 \% \\
85.2 \% \\
0.6 \%\end{array}$ & $\begin{array}{l}1.871 \\
3.059 \\
4.377 \\
0.000\end{array}$ & $\begin{array}{l}0.061 \\
0.002^{\star} \\
0.001^{*} \\
1.000\end{array}$ \\
\hline 8-EYe shape & $\begin{array}{l}\text { 1-Round } \\
\text { 2-Oval } \\
\text { 3-Narrow (slit) } \\
\text { 4-Triangular }\end{array}$ & $\begin{array}{l}17 \% \\
63 \% \\
20 \% \\
-\end{array}$ & $\begin{array}{l}2.6 \% \\
79.8 \% \\
27.2 \% \\
1.8 \%\end{array}$ & $\begin{array}{l}3.187 \\
2.472 \\
1.032 \\
0.599 \\
\end{array}$ & $\begin{array}{l}0.001^{\star} \\
0.013^{*} \\
0.302 \\
0.549\end{array}$ \\
\hline
\end{tabular}

*Significant 
Table (1): Continued:

\begin{tabular}{|c|c|c|c|c|c|}
\hline $\begin{array}{l}\text { Features } \\
\text { Category }\end{array}$ & Subset & $\begin{array}{l}\text { Percentage \% } \\
\text { in Egyptian } \\
\text { males }\end{array}$ & $\begin{array}{l}\text { Percentage \% } \\
\text { in Caucasian } \\
\text { males }\end{array}$ & $Z$ & $\boldsymbol{P}$ \\
\hline 9-Nose tip shape & $\begin{array}{l}\text { 1-Pointed } \\
\text { 2-Rounded } \\
\text { 3-Bilobed } \\
\text { 4-Hooked } \\
\text { 5-Bulbous } \\
\text { 6-Snub } \\
\end{array}$ & $\begin{array}{l}12 \% \\
53 \% \\
27 \% \\
8 \% \\
- \\
- \\
\end{array}$ & $\begin{array}{l}6.8 \% \\
66 \% \\
7.2 \% \\
2.6 \% \\
4.8 \% \\
2 \% \\
\end{array}$ & $\begin{array}{l}0.765 \\
1.729 \\
3.531 \\
1.389 \\
1.756 \\
0.711\end{array}$ & $\begin{array}{l}0.444 \\
0.084 \\
0.00^{\star} \\
0.165 \\
0.079 \\
0.477\end{array}$ \\
\hline 10-Nostril visibility & $\begin{array}{l}\text { 1-None } \\
\text { 2-Slight } \\
\text { 3-Pronounced }\end{array}$ & $\begin{array}{l}23 \% \\
36 \% \\
41 \%\end{array}$ & $\begin{array}{l}3.2 \% \\
74.8 \% \\
19.2 \%\end{array}$ & $\begin{array}{l}3.940 \\
5.377 \\
3.206\end{array}$ & $\begin{array}{l}0.001^{\star} \\
0.001^{\star} \\
0.001^{\star}\end{array}$ \\
\hline 11-Nasal alae & $\begin{array}{l}\text { 1-Compressed } \\
\text { 2-Slight } \\
\text { 3-Flaring }\end{array}$ & $\begin{array}{l}23 \% \\
36 \% \\
41 \% \\
\end{array}$ & $\begin{array}{l}8.2 \% \\
56.6 \% \\
24.8 \% \\
\end{array}$ & $\begin{array}{l}2.689 \\
2.777 \\
2.288 \\
\end{array}$ & $\begin{array}{l}0.007^{\star} \\
0.005^{\star} \\
0.022^{\star}\end{array}$ \\
\hline $\begin{array}{l}\text { 12-Upper lip } \\
\text { thickness }\end{array}$ & $\begin{array}{l}\text { 1-Thin } \\
\text { 2-Average } \\
\text { 3-Thick }\end{array}$ & $\begin{array}{l}31 \% \\
52 \% \\
17 \% \\
\end{array}$ & $\begin{array}{l}22.2 \% \\
65.2 \% \\
12.6 \% \\
\end{array}$ & $\begin{array}{l}1.248 \\
1.751 \\
0.677\end{array}$ & $\begin{array}{l}0.212 \\
0.080 \\
0.498 \\
\end{array}$ \\
\hline $\begin{array}{l}\text { 13-Lower lip } \\
\text { thickness }\end{array}$ & $\begin{array}{l}\text { 1-Thin } \\
\text { 2-Average } \\
\text { 3-Thick }\end{array}$ & $\begin{array}{l}22 \% \\
47 \% \\
31 \% \\
\end{array}$ & $\begin{array}{l}8 \% \\
58.8 \% \\
33.2 \% \\
\end{array}$ & $\begin{array}{l}2.574 \\
1.530 \\
0.182\end{array}$ & $\begin{array}{l}0.010^{\star} \\
0.126 \\
0.856\end{array}$ \\
\hline 14-Ear projection & $\begin{array}{l}\text { 1-Slight } \\
\text { 2-Medium } \\
\text { 3-Large }\end{array}$ & $\begin{array}{l}31 \% \\
56 \% \\
13 \% \\
\end{array}$ & $\begin{array}{l}30.2 \% \\
5.2 \% \\
13.4 \%\end{array}$ & $\begin{array}{l}0.031 \\
0.426 \\
0.125\end{array}$ & $\begin{array}{l}0.976 \\
0.670 \\
0.900\end{array}$ \\
\hline 15-Chin shape & $\begin{array}{l}\text { 1-Dimple } \\
\text { 2-Cleft } \\
\text { 3-Double-chin }\end{array}$ & $\begin{array}{l}31 \% \\
48 \% \\
21 \% \\
\end{array}$ & $\begin{array}{l}10.2 \% \\
33.4 \% \\
21.2 \%\end{array}$ & $\begin{array}{l}3.462 \\
1.957 \\
0.139 \\
\end{array}$ & $\begin{array}{l}0.001^{\star} \\
0.050 \\
0.890\end{array}$ \\
\hline
\end{tabular}

*Significant 
Table (2): Comparison between the studied groups as regards the anthropometric measurements.

\begin{tabular}{|l|c|c|c|c|c|}
\hline \multicolumn{1}{|c|}{ Area measured (cm)/2photographs } & $\begin{array}{c}\text { Mean } \pm S D \text { of } \\
\text { the first } \\
\text { photographs }\end{array}$ & $\begin{array}{c}\text { Mean } \pm S D \text { of } \\
\text { the second } \\
\text { photographs }\end{array}$ & $\begin{array}{c}\text { Difference } \\
\text { between } 2 \\
\text { photographs }\end{array}$ & \% change & $t$ (paired) \\
\hline Interpupillary distance & $2.015 \pm 0.210$ & $2.015 \pm 0.210$ & $0.00 \pm 0.00$ & 0.00 & 0.00 \\
\hline Horizontal face width between 2ear roots & $4.159 \pm 0.295$ & $4.161 \pm 0.296$ & $0.002 \pm 0.017$ & 0.05 & 1.32 \\
\hline Mouth width on oral fissure line & $2.145 \pm 0.467$ & $2.135 \pm 0.493$ & $0.010 \pm 0.346$ & 0.81 & 0.28 \\
\hline Nose width at widest points of alae & $1.129 \pm 0.171$ & $1.125 \pm 0.164$ & $0.004 \pm 0.109$ & 0.21 & 0.29 \\
\hline Length of forehead & $2.060 \pm 0.440$ & $2.068 \pm 0.442$ & $0.008 \pm 0.099$ & 0.54 & 0.78 \\
\hline Length of nose & $1.492 \pm 0.284$ & $1.487 \pm 0.286$ & $0.005 \pm 0.039$ & 0.33 & 1.25 \\
\hline Length of mouth and chin & $2.386 \pm 0.210$ & $2.385 \pm 0.210$ & $0.001 \pm 0.032$ & 0.02 & 0.19 \\
\hline Distance between two inner canthi & $1.115 \pm 0.155$ & $1.113 \pm 0.130$ & $0.002 \pm 0.087$ & 0.13 & 0.28 \\
\hline Width of one eye (lefi eye) & $0.804 \pm 0.146$ & $0.804 \pm 0.146$ & $0.00 \pm 0.00$ & 0.00 & 0.00 \\
\hline Distance between nostril and oral parting & $0.796 \pm 0.069$ & $0.798 \pm 0.071$ & $0.002 \pm 0.012$ & 0.13 & 0.93 \\
\hline Distance between oral parting and mental & $0.797 \pm 0.072$ & $0.795 \pm 0.074$ & $0.002 \pm 0.011$ & 0.25 & 1.70 \\
\hline sulcus & & & & & \\
\hline Distance between mental sulcus and chin & $0.7967 \pm 0.071$ & $0.7973 \pm 0.068$ & $0.0006 \pm 0.016$ & 0.13 & 0.37 \\
\hline Length of ear (left ear) & $1.6662 \pm 0.167$ & $1.6664 \pm 0.166$ & $0.0002 \pm 0.006$ & 0.02 & 0.33 \\
\hline Length of eyebrow (left eyebrow) & $1.5391 \pm 0.228$ & $1.5386 \pm 0.227$ & $0.0005 \pm 0.014$ & 0.02 & 0.36 \\
\hline
\end{tabular}

*Significant $<0.05$ 

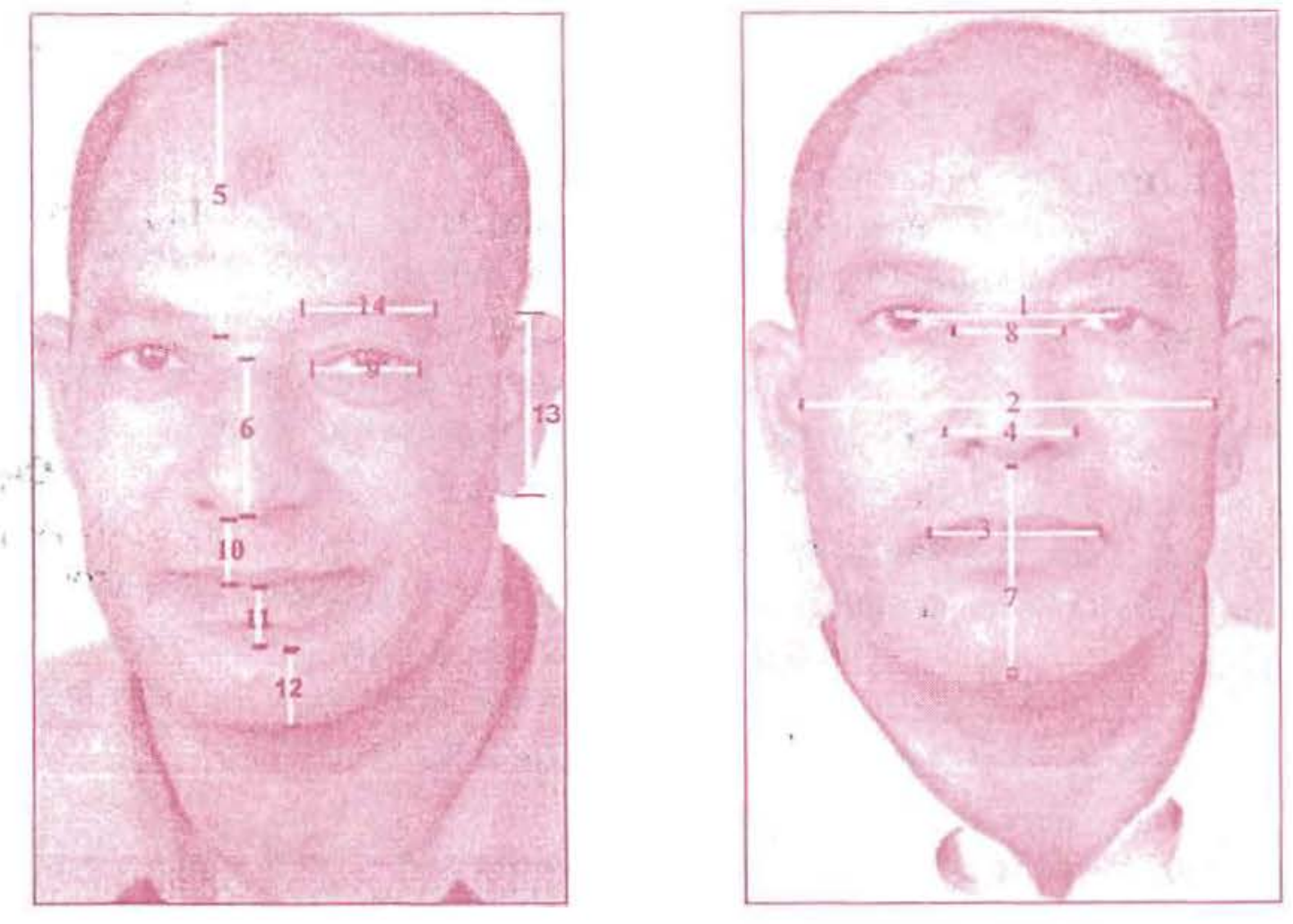

Fig. (1): Photographs showing anthropometric orientation lines. .

1 - Interpupillary distance.

2 - Horizontal face width between the two ear roots.

3 - Mouth width on the oral fissure line.

4 - Nose width at the widest points of the alae.

5 - Length of the forehead.

6 - Length of the nose.

7 - Length of the mouth and chin (from the tip of nose to the edge of chin).

8 - Distance between the eyes (area between the two inner canthi).

9 - Width of the left eye.

10- Distance between the nostril and the oral parting.

11- Distance between the oral parting and the mental sulcus.

12- Distance between the mental sulcus and the edge of the chin.

13- Length of the left ear.

14- Length of the left eyebrow. 


\section{REFERENCES}

Aulsebrook, W. A.; Becker, P. J. and Iscan, M, Y. (1996) : "Facial soft tissue thickness in adult male zulu ". Forensic Science International, 79: 83-102.

Benson, P. J. (1994) : " On facial composite image prototyping as a descriptive and diagnostic tool". J. Audiov. Media Med., 17(1): 27-30.

Bush, K. and Antonyshyn, O. (1996): "Three dimensional facial anthropometry using a laser surface scanner: Validation of the technique". Plast. Reconstr. Surg., 98 (2): 226-235.

Catterick, T. (1992) : " Facial measurements as an aid to recognition". Forensic Science International, 56:23-27.

Dawson-Saunders, B. and Trapp, R. (1994) : Basic and Clinical Biostatics. 2nd edition, Lang Medical Book, Prentice- Hall International Inc.

Farkas, L. G. and Kolar, J. G. (1987) : "Anthropometrics and art in the anaesthetics of women 's face". Clin. Reconstr. Surg.,14: 599.

Farkas, L. G.; Hreczko, T. A.; Kolar, J. G. and Munro, I. R. (1985) : "Vertical and horizontal proportions of the face in young adult North American Caucasians:
Revision of neoclassical canons". Plast. Reconstr. Surg.,75: 328.

Farkas L. G.; Ross R. B. and James, J. S. (1977) : "Anthropometry of the face in lateral facial dysplasia: The bilateral form". Cleft Palate J., 14: 41.

Farkas, L. G.; Ross, R. B. ; Posnick, J. C. and Indech, G. D. (1989) : "Orbital measurements in 63 hyperteloric patients: Differences between the anthropometric and cephalometric findings". J. Craniomaxillofac. Surg.,17: 249.

Fraklin, C. A. (1988) : Personal identity. In : Medical Jurisprudence and Toxicology. 21 ed., Bombay N.M. Tripathi Private limited, P.52.

Henham, A. P. and Lee, K. A. (1994) : "Photography in forensic medicine ". J. Audiov. Media Med., 17(1): 15-20.

Knight, B. (1996) : The establishment of identity of human remains. In : Forensic Pathology. Edward Arnold (Ed.), A division of Hodder and Stoughton, London, Melbourne, Auckland, P.P.96, 130-132.

Loh, F. C. and Chao, T. C. (1989): "Skull and photographic superimposition: a new approach using a third party ' $s$ interpupillary distance to extrapolate the magnification factor". J. Forensic Sci., 34:708-713. 
Miyasaka, S.; Yoshino, M.; Imaezumi, K. and Seta, S. (1995) : "The computer aided facial reconstruction system ". Forensic Science International,74: 155-165.

Porter, G. and Doran, G. (2000) : " An analonical and photographic technique for forensic facial identification". Forensic Science International, 114: 97-105.

Salmons, S. (1995) : Muscle. In: Gray's Anatomy. Williams, P.L.; Bannister, L.H.; Berry, M.M.; Collins, P.; Dyson, M.; Dussek, J.E.; Ferguson M.W.J.(Eds.), 38th. ed, Churckill Living Stone, New York, Edinburgh, London, Tokyo, Madrid, Melbourne,P.P.792-794.
Vanezis, P.; Lu, D.; Cockburn, J.; Gonzalez, A.; Mc Conbe, G.; Trujillo, O. and Vanezis, M. (1996) : " Morphological classification of facial features in adult Cauca. sian males based on an assessment of photographs of 50 subjects". J. Forensic Sci., 41(5):786-791.

Vegter, F. and Hage, J. J. (2000): "Clinical anthropometry and canon of the face in historical perspective ". Plast. Reconstr. Surg., 106 (5): 1090-6.

Vezjak, M. and Stephancic, M. (1994) : "An anthropological model for automatic recognition of the male human face ". Ann. Hum. Biol., 21(4): 363-80. 


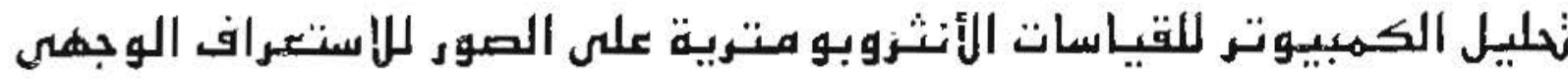 للرجال الهصريبين البالغين
}

\author{
المشتركون فى البحث

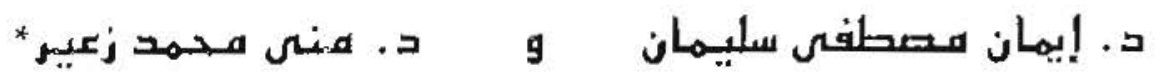 \\ * من أتسام الطب ألشرعى والسعرم ألإكلينيكية رعلم التشريح والأجنة \\ كلبة الطب - جامعة طنط
}

$\therefore$

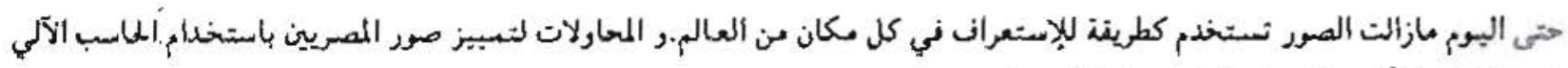
تليلة عن الظواهر الأخرى المستخدمة في هياتنا اليومية.

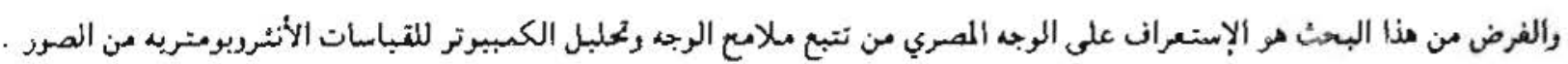

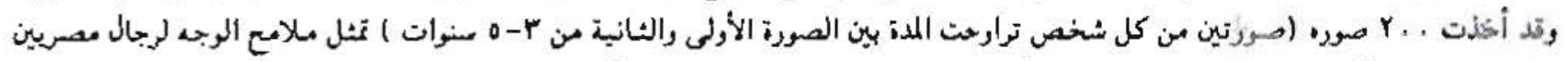

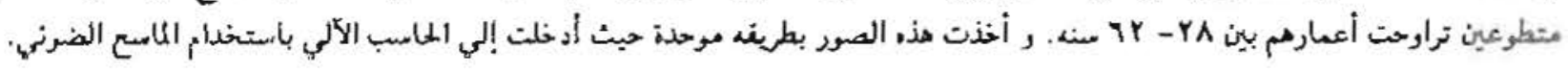

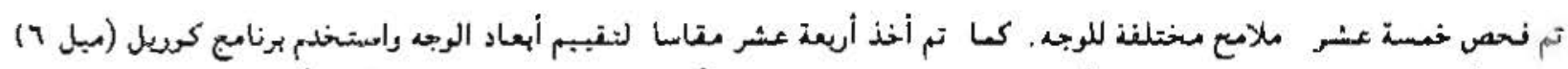

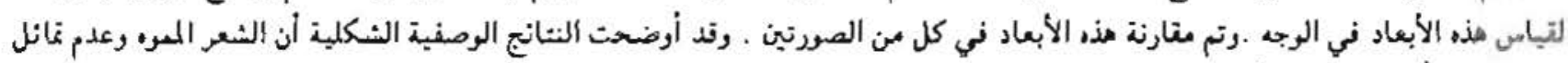

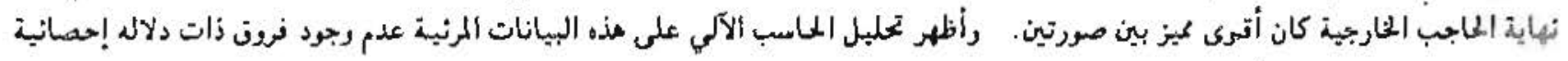

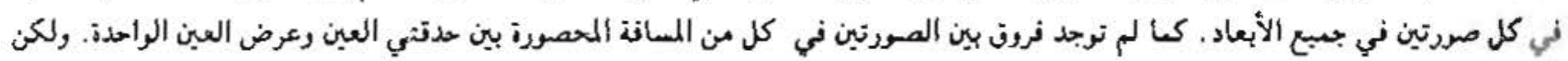

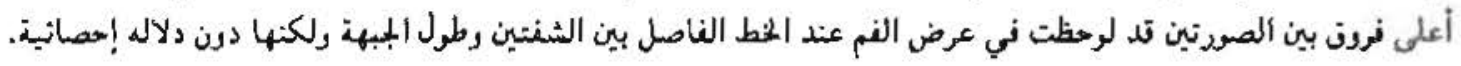

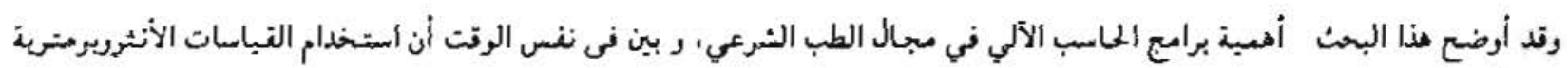

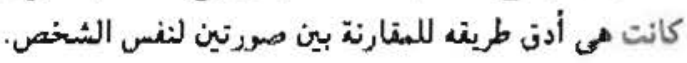

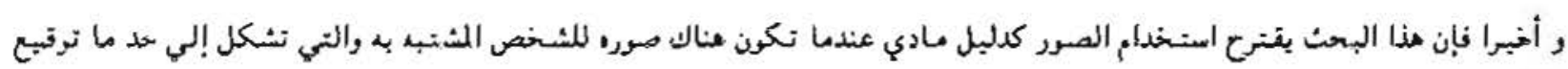
يتركه المثتبب به خلفه كدليل. 